\title{
Performa Model Tes Hidrolis Untuk PLTMH Head Rendah dengan Menggunakan Tekanan Aliran dan Kecepatan Pusaran Air (Vortex)
}

\author{
Suhartono $^{1}$, Ratih Indri Hapsari ${ }^{2}$, Mohamad Zenurianto ${ }^{3}$, dan Ikrar Hanggara ${ }^{4}$ \\ 1,2,3,4 Jurusan Teknik Sipil Politeknik Negeri Malang
}

*e-mail corresponding author : ${ }^{4} \mathrm{k} k$ rarhanggara@gmail.com

\begin{abstract}
ABSTRAK
Perkembangan kehidupan manusia sangat dipengaruhi oleh keberadaan energi listrik. Oleh karena itu perlu dilakukan penelitian terkait pembangkitan energi listrik dalam skala kecil (mikro). Salah satu alternatif pembangkit listrik dengan mengubah energi gerak dilakukan dengan memanfaatkan aliran air. Aliran air dengan debit dan beda tinggi (head) yang rendah sudah ditemukan di beberapa tempat, terutama sungai kecil atau saluran irigasi. Pemanfaatan debit dan beda tinggi air yang rendah adalah potensi besar untuk dapat menghasilkan energi listrik skala kecil (mikro). Dalam penelitian ini, pemodelan aliran rendah dan pelepasan head rendah akan dilakukan untuk mengetahui seberapa besar potensi energi listrik dapat dihasilkan. Ada 3 percobaan yaitu tenaga air, pusaran air, jatuh tinggi. Variabel yang digunakan dalam percobaan ini adalah berbagai kepala yang berbeda di cekungan (dalam percobaan 1; 0,2 meter, 0,3 meter, 0,4 meter dan 5 meter) untuk menghasilkan debit spesifik yang dapat membuat aliran verteks dan kecepatan baling-baling dari aliran terjun. Metode yang digunakan dalam penelitian ini adalah pengukuran dasar menggunakan instrumental flow digital dan dan setup flow menggunakan valve. Eksperimen 1 dengan kepala 50 meter menemukan 1.414 watt tenaga air dengan laju pelepasan 17,3 liter/menit pada pipa berdiameter 1". Dalam percobaan 2 kinerja alat tidak dapat menghasilkan aliran pusaran sesuai dengan rencana, karena luas penampang tidak sebanding dengan lubang luar cekungan dan hanya menghasilkan simpul pada kedalaman aliran $10 \mathrm{~cm}$ dan menghasilkan radius pusaran $1 \mathrm{~cm}$. Dalam Percobaan 3 kinerja alat dapat berjalan dengan baik stabilitas debit yang dihasilkan dari sedative bath menunjukkan bahwa kecepatan aliran yang diukur sesuai dengan kondisi laju aliran teoritis, yaitu kecepatan aliran meningkat karena jatuh tinggi.
\end{abstract}

\section{Kata Kunci : vortex, PLTMH, model test hidrolik}

\section{ABSTRACT}

The development of buman life is greatly influenced by the presence of electrical energi. Therefore it is necessary to conduct research related to the generation of electrical energi on a small scale (micro). One alternative electricity generation by changing the motion energi is done by utilizing the flow of water. Water flow with low discharge and head is easily found in several places, especially small rivers or irrigation channels. Utilization of low flow head and discharge is a great potential to be able to produce small-scale (micro) electrical energi. In this research, modeling of low flow and low head discharge will be carried out to find out how much potential the electrical energi can generate. There are 3 experiments namely water power, whirlpool, high fall. The variable that used in this experiment is various different head on the

Cara Mengutip : Suhartono, S., Hapsari, R. I., Zenurianto, M., Hanggara, I. (2020). Performa Model Tes Hidrolis Untuk PLTMH Head Rendah dengan Menggunakan Tekanan Aliran dan Kecepatan Pusaran Air (Vortex). Reka Buana : Jurnal Ilmiah Teknik Sipil dan Teknik Kimia, 5(1), 28-36. http://dx.doi.org/10.33366/ rekabuana.v5i1.1573 
basin (in experiment 1; 0.2 meters, 0.3 meters, 0.4 meters, and 5 meters) to generate specific discharge that can make vortex flow and the velocity of the propeller from plunge flow. The methodes that used in this experiment is basic measurement using instrumental flow digital and setup flow using the valve. Experiment 1 with a head of 50 meters found 1,414 watts of water power with a discharge rate of 17.3 liters/minute on a 1 "diameter pipe. In experiment 2 the performance of the tool could not produce a vortex flow according to the plan, because the cross-sectional area was not comparable to the basin's outer hole and only produced vertices at a depth of $10 \mathrm{~cm}$ flow and produced a vortex radius of $1 \mathrm{~cm}$. In Experiment 3 the performance of the tool can run well the stability of the discharge generated from the sedative bath shows that the measured flow velocity is in accordance with the theoretical flow rate conditions. Ie the speed of flow increases due to high fall.

Keywords : vortex, PLTMH, hydraulic test model

\section{PENDAHULUAN}

Energi Listrik merupakan sumber energi utama dalam kehidupan manusia. Perkembangan kehidupan manusia sangat dipengaruhi oleh keberadaan energi listrik tersebut. Oleh karena hal tersebut maka perlu dilakukan perkembangan pembangkitan energi listrik dalam skala kecil (mikro). Salah satu alternatif pembangkitan energi listrik dengan mengubah energi gerak dilakukan dengan memanfaatkan aliran air. Aliran air dengan debit dan head rendah mudah ditemukan dibeberapa tempat khususnya sungai kecil atau saluran irigasi. Pemanfaatan aliran debit dan head rendah ini merupakan potensi besar untuk bisa menghasilkan energi listrik skala kecil (mikro).

Aliran dalam debit yang kecil ataupun head yang kecil merupakan tantangan besar kepada peneliti untuk dapat membuat energi listrik yang dapt bermanfaat dengan kekurangan tersebut. Salah satu upaya dalam pembangkitan energi listrik dari energi gerak yaitu memanfaatkan pusaran air. Pusaran (Vortex) ini merpakan salah satu alternatif pembangkitan energi yang bisa dilihat secara langsung pergerakannya tampak mempunyai aliran yang kencang dengan mengandalkan debit dan head yang rendah.
Fenomena vortex merupakan fenomena pusaran aliran yang terjadi akibat lubang pada penampang bawah aliran/ tampungan. Penelitian Mulligan (2010) [1], dalam penelitian yang berjudul "Design And Optimisation of $A$ Water Vortex Hydropower Plant' didapatkan bahwa kekuatan optimum aliran vortex terjadi pada rasio diameter lubang outlet dengan basin antara 14\%-18\%, tinggi dari vortex berbanding lurus dengan debit (discharge), tinggi dan kapasitas air, daya teoritis maksimal $=\mathrm{egQHv}(\mathrm{Hv}=$ height of vortex). Didalam penelitian ini diketahui bahwa turbin aliran vortex cocok dikembangkan pada daerah yang memiliki sumber air dengan debit yang cukup besar (sungai) namun hanya memiliki head yang rendah.

Menurut Zainudin (2017) [2] Fenomena aliran pusaran (vortex) sering kali kita temukan pada pemodelan sayap pesawat dan bendungan air, Keuntungan Fenomena vortex salah satunya adalah turbin vortex. Kerugian yang ditimbulkan oleh Fenomena vortex salah satunya adalah pada pengoperasian turbin pelton, dimana turbin pelton sangat tergantung pada laju aliran fluida dari bendungan. Fenomena vortex yang terjadi memang sangat sulit untuk diamati karena pada saat terjadinya fenomena vortex yang relatif singkat, perlu 
alat uji vortex agar bisa mempelajari fenomena vortex yang terjadi dan membandingkan dengan teori yang dipelajari.

Menurut Irawan dwi (2014) [3] Energi air dapat dimanfaatkan sebagai pembangkit listrik dengan memanfaatkan tenaga potensial yang tersedia (potensi air terjun dan kecepatan aliran). Berdasarkan data Blueprint Pengelolaan Energi Nasional tahun (2005) [4],

Berdasarkan latar belakang tersebut penulis mencoba untuk membuat model aliran debit rendah dengan menggunakan tandon buatan yang kemudian disalurkan melalui pipa saluran bertekanan untuk membangkitkan aliran pusaran (vortex) dengan menyesuaikan debit melalui katub pengatur tekanan dan membandingkan kinerja alat tersebut dengan aliran memanfaatkan tinggi jatuh untuk memutar propeller yang didalam penelitian ini menggunakan current meter untuk mengukur kecepatan aliran.

Sesuai dengan latar belakang tersebut, maka dapat dibuat rumusan masalah sebagai acuan pembahasan permasalahan yang akan dikaji yaitu mengenai kinerja / performa alat untuk membuat aliran tekanan debit rendah dan kajian performa aliran vortex yang terjadi pada alat. Tujuan penelitian ini adalah membuat alat simulasi (model) untuk mengetahui karakteristik aliran khususnya untuk debit dan head rendah untuk dimanfaatkan sebagai penggerak turbin pada PLTMH.

\section{METODE PENELITIAN}

Material yang digunakan dalam penelitian ini adalah:

1. Rangka besi (besi siku)

2. Papan Triplek
3. Flow meter

4. Pipa PVC 1"

5. Katup

6. Pompa

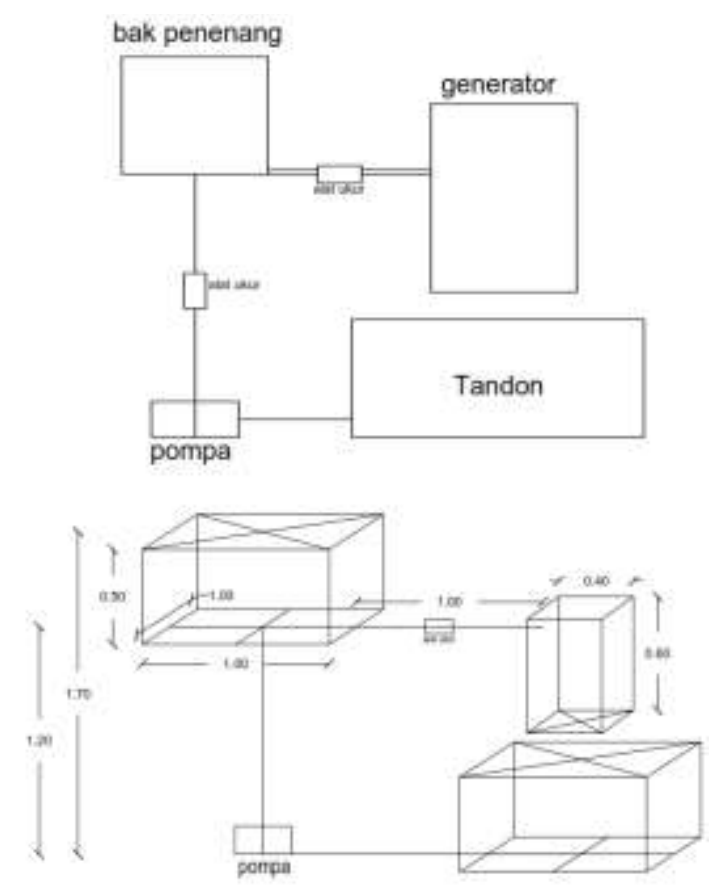

Gambar 1. Skema alat

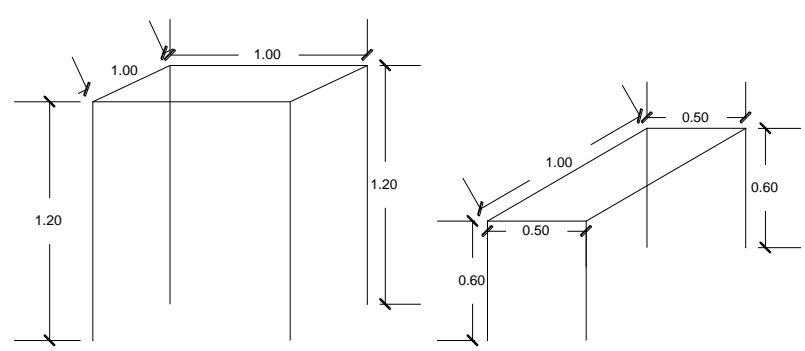

Gambar 2. Dimensi rangka penyangga

\section{Variabel Penelitian}

Variabel bebas merupakan variabel yang menjadi sebab perubahannya atau timbulnya variabel terikat. Dalam penelitian ini variabel bebasnya yaitu Head: $20 \mathrm{~cm}, 30$ $\mathrm{cm}, 40 \mathrm{~cm}, 50 \mathrm{~cm}$ pada 3 percobaan:

1. Daya Air

2. Pusaran Air

3. Tinggi jatuh 
Variabel terikat dalam penelitian ini merupakan variabel yang dipengaruhi atau yang menjadi akibat karena adanya variabel bebas. Dalam penelitian ini variabel terikatnya adalah daya yang dihasilkan oleh aliran air yang dihitung secara teoritis. Variabel tetap / control dalam penelitian ini adalah variabel yang dikendalikan atau dibuat konstan sehingga pengaruh variabel independen terhadap dependen tidak dipengaruhi oleh faktor luar yang tidak diteliti. Variabel kontrol dalam penelitian ini yaitu :

1. Luas Basin : $1600 \mathrm{~cm}^{2}$

2. Tinggi basin : $60 \mathrm{~cm}$

3. Menggunakan propeller 6 sudu yang dihubungkan dengan pembacaan digital.

4. Material sudu terbuat dari plastik $2 \mathrm{~mm}$

5. Fluida kerja adalah air

6. Diameter outlet basin 1"

Alat yang digunakan dalam penelitian ini adalah:

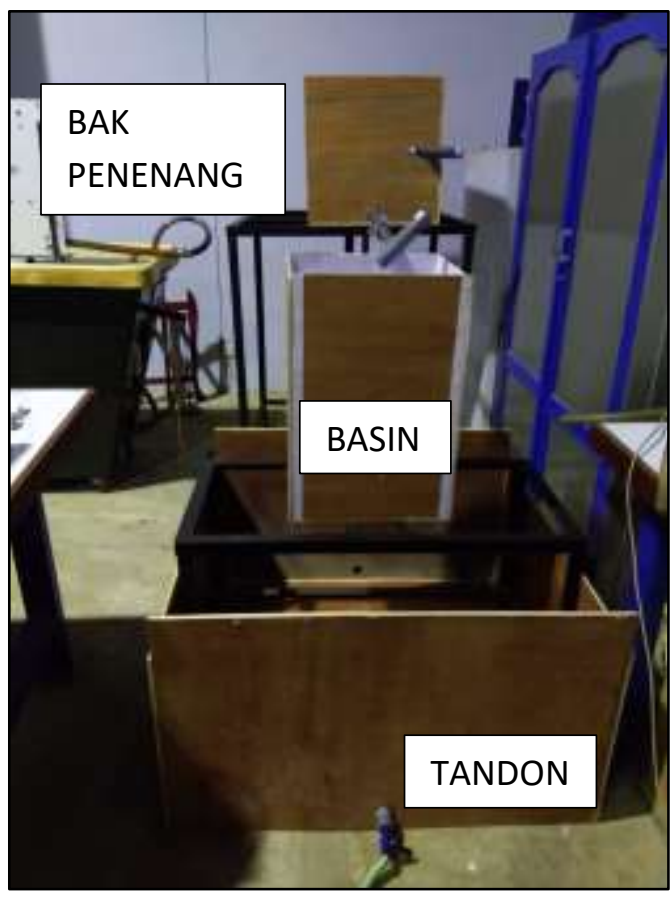

Gambar 3. Alat Model Tes Tampak Samping

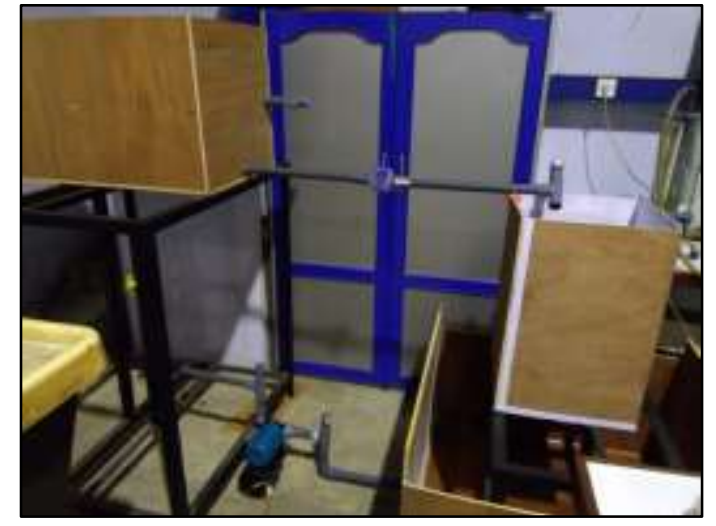

Gambar 4. Alat Model Tes Tampak Depan

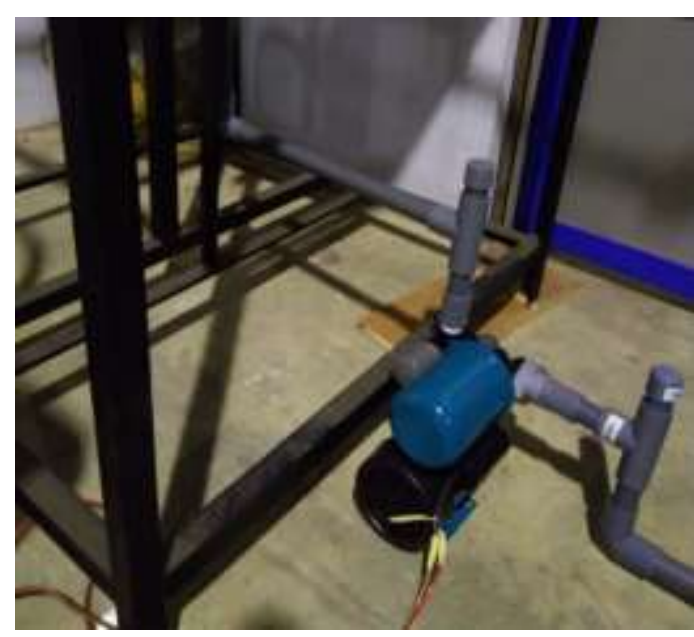

Gambar 5. Pompa Sentrifugal

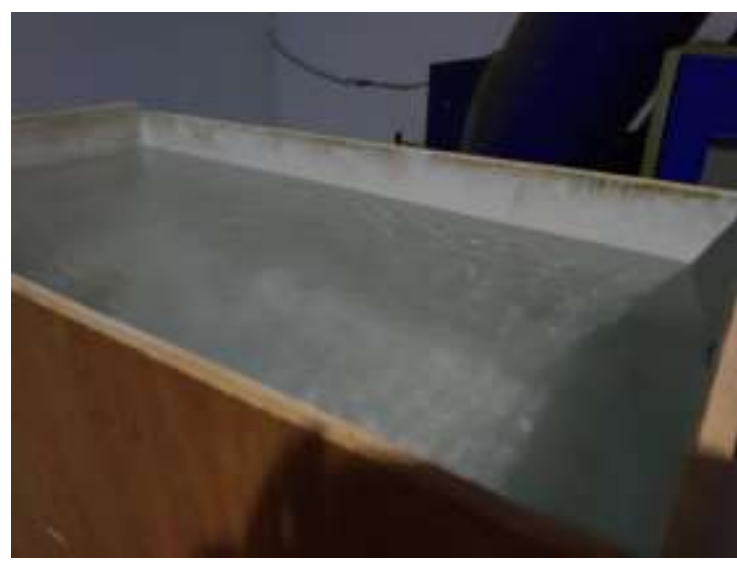

Gambar 6. Bak Penenang

\section{Instrumen penelitian}

Peralatan instrument yang digunakan adalah: 


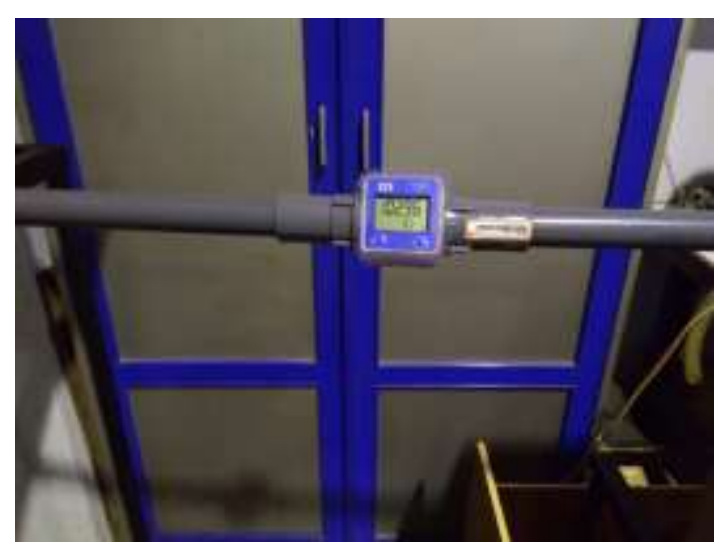

Gambar 7. Flow Meter

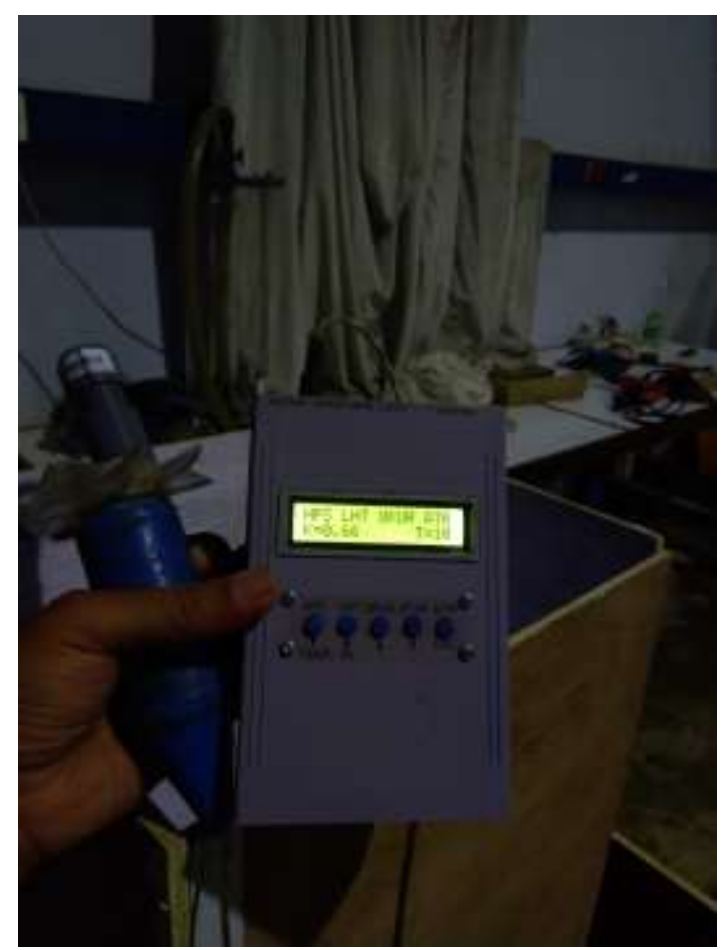

Gambar 8. Propeller (current meter)

\section{Prosedur penelitian}

Berikut ini adalah prosedur pengambilan data penelitian variasi Head / ketinggian dan debit (kapasitas aliran) yaitu mempersiapkan instalasi model bangunan beserta alat pendukungnya. Mengecek pipa dan semua sambungan telah tersambung kuat dan tidak bocor. Lalu mengisi tandon penampung hingga mencapai ketinggian 50 $\mathrm{cm}$ atau setara dengan volume 500 liter.
Menyalakan pompa hingga air mengalir menuju basin / generator dan kembali ke dalam tendon. Mengatur katup pada pipa menuju bak penenang untuk mendapatkan head / ketinggian air : $20 \mathrm{~cm}, 30 \mathrm{~cm}, 40 \mathrm{~cm}$, $50 \mathrm{~cm}$.

Selanjutnya membaca digital flow meter untuk mengetahui besarnya debit yang melewati pipa menuju basin/ generator. Pencatatan debit dilakukan dengan merata-rata bacaan yang terbaca secara fluktuatif. Mengukur kecepatan jatuh aliran terhadap propeller yang diletakkan tepat di depan pipa untuk masing-masing head/ketinggian. Membiarkan basin terisi dan catat ketinggian vortex yang terjadi pada basin. Kemudian ulangi langkah diatas untuk mendapatkan semua variable bebas yang hendak diukur.

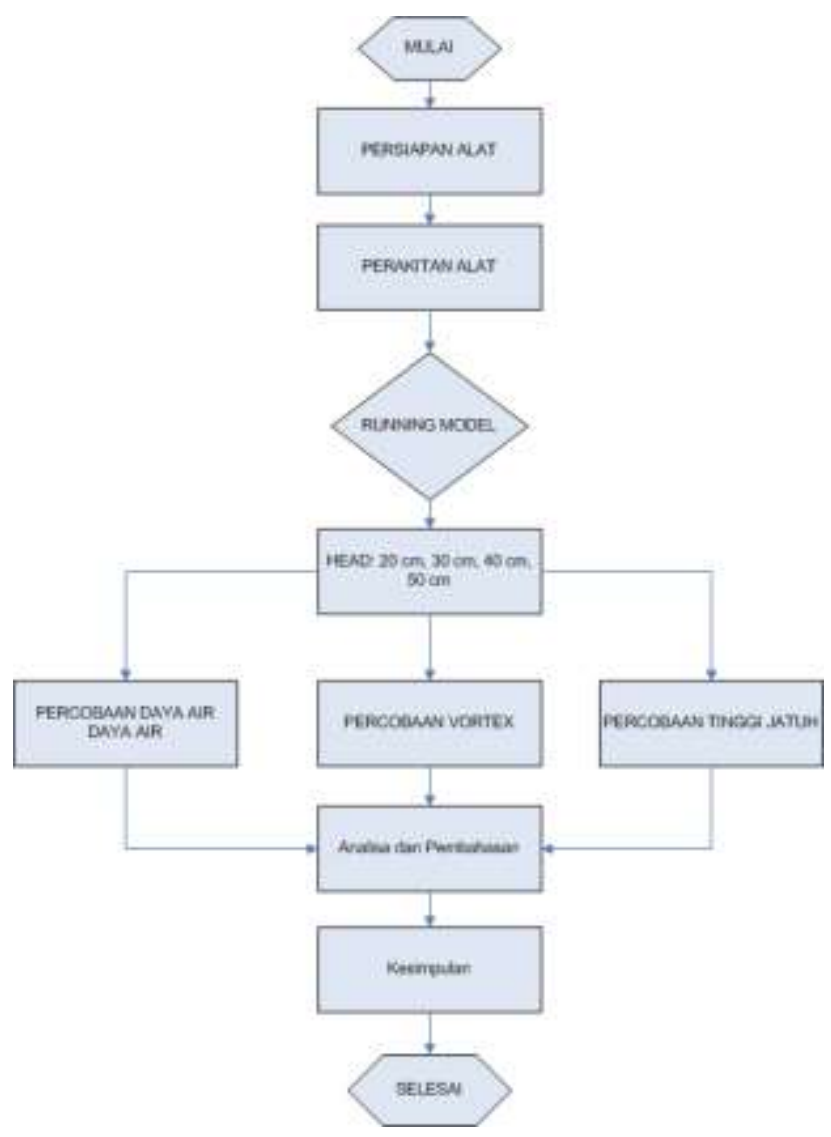

Gambar 9. Flow Chart Pelaksanaan 


\section{HASIL DAN PEMBAHASAN}

Penelitian ini bertujuan untuk mendapatkan besaran daya air untuk tiap variasi head dan debit. performa yang dikaji adalah:

1. Aliran dalam kondisi tertekan sehingga mengakibatkan tekanan yang dapat memutar propeller bacaan untuk mengetahui kecepatan putaran yang dihasilkan untuk beberapa variasi ketinggian.

2. Besarnya kecepatan yang dihasilkan dari debit yang direncanakan pada basin/generator pembangkit yang direncanakan menghasilkan vortex.

Hal pertama yang dilakukan dalam penelitian ini (percobaan 1) adalah melakukan pengaturan katup agar didapatkan ketinggian/head yang direncanakan yaitu $20 \mathrm{~cm}, 30 \mathrm{~cm}, 40 \mathrm{~cm}, 50 \mathrm{~cm}$ pada bak penenang. Setiap ketinggian kemudian dibaca berapa debit bacaan pada flow meter. Pembacaan flow meter dilakukan dengan merata-bacaan selama tiga kali perubahan sampai didapatkan bacaan stabil.

Perhitungan daya air yang mengalir dilakukan dengan menggunakan rumus yaitu, Daya air teoritis dapat dihitung dengan menggunakan persamaan sebagai berikut :

$$
P_{a}=\rho \cdot Q \cdot g \cdot H
$$

Keterangan:

$P_{a}=$ Daya Air (watt)

$\rho=$ Massa Jenis $\left(\mathrm{kg} / \mathrm{m}^{3}\right), \rho_{\text {air }}=1000 \mathrm{~kg} / \mathrm{m}^{3}$

$\mathrm{Q}=$ Debit Aliran $\left(\mathrm{m}^{3} / \mathrm{dt}\right)$

$\mathrm{g}=$ Grafitasi $\left(\mathrm{m} / \mathrm{s}^{2}\right), \mathrm{g}=9.81 \mathrm{~m} / \mathrm{s}^{2}$

$\mathrm{H}=$ Head (tinggi permukaan air) (meter)

Berikut adalah hasil dari perhitungan variasi head / ketinggian tekan hidrolis terhadap bangkitan daya teoritis
Tabel 1. Perhitungan Daya Air pada hasil pembacaan data debit pada Flow meter

\begin{tabular}{cccc}
\hline $\begin{array}{c}\text { Head } \\
\text { (meter) }\end{array}$ & $\begin{array}{c}\mathrm{Q} \\
\text { (liter/menit) }\end{array}$ & $\begin{array}{c}\mathrm{Q} \\
(\mathrm{m} 3 / \mathrm{dt})\end{array}$ & $\begin{array}{c}\mathrm{Pa} \\
\text { (watt) }\end{array}$ \\
\hline 0.2 & 6.8 & 0.000113 & 0.22 \\
\hline 0.3 & 10.3 & 0.000172 & 0.51 \\
\hline 0.4 & 13.8 & 0.00023 & 0.90 \\
\hline 0.5 & 17.3 & 0.000288 & 1.41 \\
\hline
\end{tabular}

HUBUNGAN ANTARA HEAD DENGAN DAYA AIR

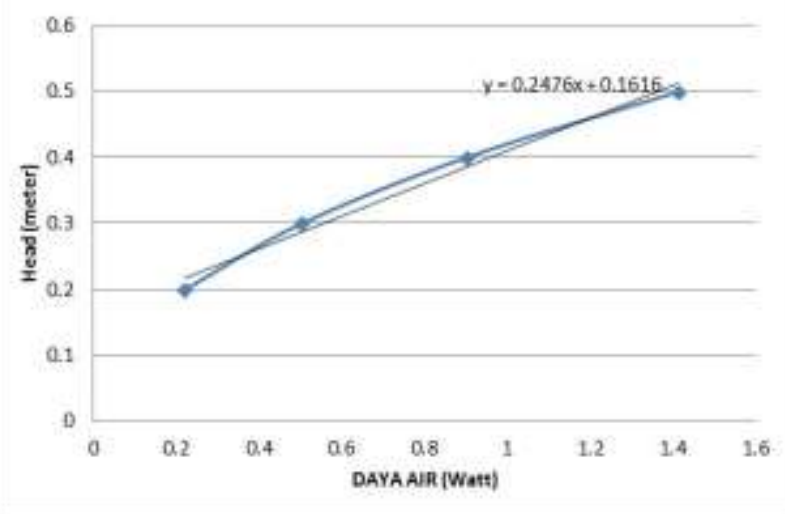

Gambar 10. Kurva lengkung Head VS Daya Air dengan menggunakan pipa 1"

Dari grafik diatas dapat dilihat bahwa hubungan antara head dengan bangkitan daya teoritis tidak bersifat linier. Dari grafik diatas pada head yang lebih tinggi akan didapatkan kenaikan daya yang signifikan. Untuk mendapatkan variasi hubungan yang lebih beragam untuk penelitian selanjutnya bisa dilakukan percobaan variasi dengan merubah dimensi diameter pipa.

Percobaan berikutnya dengan melakukan pengisian pada basin / generator pembangkit pusaran air untuk masingmasing head. Langkah yang dilakukan adalah mengatur bukaan katub untuk setiap head kemudian dilakukan perhitungan kecepatan pusaran air yang terjadi akibat head yang berbeda tersebut. Hasil dari percobaan 2 didapatkan sebagai berikut, 
Tabel 2 Data aliran percobaan $2(\operatorname{Head} 20-50 \mathrm{~cm})$

\begin{tabular}{ccc}
\hline $\mathbf{H}$ air & H vortex $(\mathrm{cm})$ & $\mathbf{r}$ vortex $(\mathrm{cm})$ \\
\hline 10 & 5 & 1 \\
\hline 20 & 0 & 0 \\
\hline 30 & 0 & 0 \\
\hline 40 & 0 & 0 \\
\hline 50 & 0 & 0 \\
\hline
\end{tabular}

Data diatas merupakan data aliran pusaran vortex bebas yaitu pusaran yang ditimbulkan oleh vortex hanya dipengaruhi oleh lubang luaran pada basin. Data yang dikumpulkan pada semua kondisi head mulai $20 \mathrm{~cm}$ sampai $50 \mathrm{~cm}$. sehingga dalam percobaan ini dapat disimpulkan bahwa pengaruh dari aliran tekanan pada basin untuk menimbulkan vortex bebas dipengaruhi oleh oleh lubang dan debit pada pengisian basin. Untuk pengembangan variasi berikutnya pada kinerja percobaan 2 dapat dilakukan variasi diameter dan bentuk penampang basin untuk dapat diketahui karakteristik aliran vortex yang lebih spesifik. Untuk hasil percobaan 2 diatas perhitungan aliran vortex dapat dihitung dengan rumus,

$$
v=\frac{k}{r}
$$

Keterangan:

$\mathrm{v}=$ Kecepatan aliran vortex $(\mathrm{m} / \mathrm{dt})$

$\mathrm{k}=$ Koefisien Vortex $\left(\mathrm{m}^{2} / \mathrm{dt}\right)$

$\mathrm{r}=$ Jari-jari vortex (meter)

$$
k=\sqrt{2 \cdot g \cdot \Delta H \cdot r}
$$

Keterangan:

$\mathrm{g}=$ Grafitasi $\left(\mathrm{m} / \mathrm{s}^{2}\right)$

$\Delta H=$ tinggi vortex (meter)

$\mathrm{r}=$ Jari-jari vortex (meter)

dari rumus diatas maka didapatkan,

$k=\sqrt{2 \times 9.81 \times 0.1 \times 0.01}$

$k=0.14007141=0.14 \mathrm{~m}^{2} / \mathrm{dt}$
Sehingga kecepatan vortex dapat ditentukan yaitu,

$$
\begin{aligned}
& v=\frac{0.14}{0.01} \\
& v=9.9 \mathrm{~m} / \mathrm{dt}
\end{aligned}
$$

Pada percobaan berikutnya (percobaan 3) dilakukan pengukuran kecepatan aliran dengan melakukan tinggi jatuh pada aliran tertekan melalui pipa dengan variasi head / ketinggian muka air. Berikut hasil pengukuran kecepatan tinggi jatuh menggunakan propeller 6 sidu (balingbaling)

Tabel 3 Data aliran percobaan $3($ Head $20-50 \mathrm{~cm})$

\begin{tabular}{cccc}
\hline $\begin{array}{c}\text { Head } \\
\text { pada } \\
\text { tandon } \\
(\mathrm{m})\end{array}$ & $\begin{array}{c}\text { Tinggi Jatuh } \\
\text { hilir dengan } \\
\text { propeler }(\mathrm{m})\end{array}$ & $\begin{array}{c}\text { Bacaan } \\
\text { Propeler } \\
(\mathrm{m} / \mathrm{dt})\end{array}$ & $\begin{array}{c}\text { Pa } \\
\text { (watt) }\end{array}$ \\
\hline \multirow{3}{*}{0.5} & 0.1 & 1.1 & 0.28 \\
\cline { 2 - 4 } & 0.2 & 1.7 & 0.57 \\
\cline { 2 - 4 } & 0.4 & 2.3 & 1.13 \\
\hline \multirow{3}{*}{0.4} & 0.1 & 0.9 & 0.23 \\
\cline { 2 - 4 } & 0.2 & 1.5 & 0.45 \\
\hline \multirow{3}{*}{0.3} & 0.4 & 2 & 0.90 \\
\cline { 2 - 4 } & 0.1 & 0.8 & 0.17 \\
\cline { 2 - 4 } & 0.2 & 1.3 & 0.34 \\
\hline \multirow{3}{*}{0.2} & 0.4 & 1.8 & 0.67 \\
\cline { 2 - 4 } & 0.1 & 0.5 & 0.11 \\
\cline { 2 - 4 } & 0.2 & 0.8 & 0.22 \\
\hline
\end{tabular}

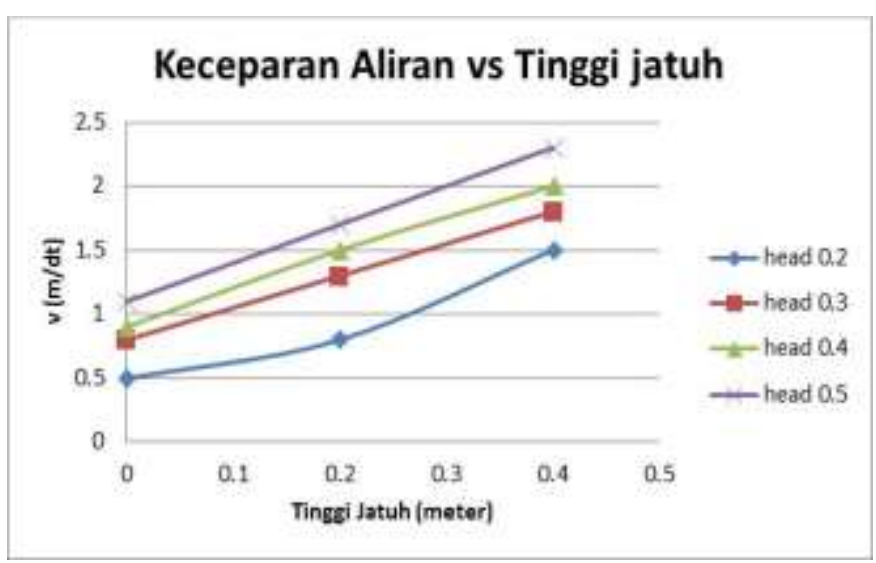

Gambar 11. Kecepatan aliran pada tinggi jatuh 
Dari grafik diatas (Gambar 11) dapat dilihat bahwa kinerja alat bekerja baik dan sesuai dengan perkiraan bahwa kecepatan aliran akan bertambah pada kondisi aliran dengan tinggi jatuh.

Pada tabel 3 untuk daya yang dihasilkan dengan head pada tandon sebesar 0.5 meter (menghasilkan Q sebesar $0.000288 \mathrm{~m}^{3} / \mathrm{dt}$ ) pada tinggi jatuh antara hilir pipa saluran dengan propeller yaitu setinggi 0.4 meter menghasilkan daya teoritis sebesar 1.13 watt.

Berdasarkan percobaan 2 yaitu pembangkitan aliran vortex, untuk tinggi pusaran setinggi $1 \mathrm{~cm}$ didapatkan kecepatan sebesar $9.9 \mathrm{~m} / \mathrm{dt}$. Kecepatan tersebut jika dibandingkan dengan kecepatan yang dihasilkan oleh tinggi jatuh setinggi 0.4 meter (yaitu sebesar $2.3 \mathrm{~m} / \mathrm{dt}$ ) adalah 4.3 kali lipat lebih besar daripada kecepatan tinggi jatuh. Sehingga penulis masih optimis bahwa aliran vortex ini dapat menghasilkan daya yang lebih besar dibandingkan dengan menggunakan tinggi jatuh.

\section{KESIMPULAN}

Berdasarkan hasil pengukuran dan pengujian data kinerja model tes hidrolis untuk PLTMH head rendah dengan menggunakan tekanan aliran dan kecepatan pusaran air (vortex) didapatkan kesimpulan sebagai berikut:

1. Performa alat secara keseluruhan dapat berjalan dengan baik, untuk percobaan 1 dengan head sebesar 50 meter didapatkan daya air sebesar 1.414 watt dengan besaran debit 17.3 liter/menit pada saluran pipa dengan diameter 1". Pada percobaan 2 kinerja alat tidak dapat menghasilkan aliran vortex sesuai dengan perencanaan, dikarenakan luasan penampang yang tidak sebanding lubang luaran basin dan hanya menghasilkan vortex pada kedalaman aliran $10 \mathrm{~cm}$ dan menghasilkan jari-jari vortex sebesar 1 $\mathrm{cm}$. Pada pecobaan 3 kinerja alat dapat berjalan dengan baik kestabilan debit yang dihasilkan dari bak penenang menunjukkan bahwa kecepatan aliran yang terukur sesuai dengan kondisi kecepatan aliran secara teoritis. Yaitu kecepatan aliran bertambah akibat tinggi jatuh.

2. Performa aliran vortex hanya mampu membuat vortex dengan ketinggian 10 $\mathrm{cm}$. sehingga dapat dikatakan kinerja alat pada percobaan aliran vortex tidak berjalan dengan baik.

Adapun saran dari peneliti terkait performa alat adalah:

1. Pada percobaan 1 kinerja alat dapat dikembangkan dengan melakukan variasi pada pipa untuk mendapatkan profil daya air yang berbeda akibat debit aliran yang berbeda.

2. Pada percobaan 2 melakukan redesain terhadap basin (generator pusar air) sehingga aliran vortex dapat diamati secara jelas dan lebih detail.

3. Pada penelitian berikutnya dapat ditambahkan instalasi turbin/generator pembangkit untuk menguji model agar mendapatkan nilai daya yang sesuai (tidak teoritis) serta penambahan instrument ukur pada beberapa masukan atau luaran dari bak penenang maupun basin.

\section{UCAPAN TERIMA KASIH}

Ucapan terima kasih penulis sampaikan kepada P2M Politeknik Negeri Malang untuk skema pendanaan DIPA Reguler 2019 sehingga penelitian ini dapat berjalan dengan bantuan / hibah dana tersebut. 


\section{DAFTAR PUSTAKA}

[1] Mulligan, S., and P. Hull. 2010. Design And Optimisation Of A Water Vortex Hydropower Plant, (Online), https://itsligo.ie/wp-includes/msiles.php?file $=2011 / 03 /$ Sean-MulliganA0.pdf

[2] Zainudin, Zainudin Zainudin, and Basuki Rahmat. (2019). "Pengujian Alat Uji Vortex Bebas dan Vortex Paksa." Zona Mesin 8(3) Tahun 2019.
[3] Irawan, Dwi. "Prototype Turbin Pelton Sebagai Energi Alternatif Mikrohidro Di Lampung." Turbo: Jurnal Program Studi Teknik Mesin 3.1 (2014).

[4] Kementerian Energi dan Sumber Daya Mineral. 2009.Master Plan Pembangunan Ketenagalistrikan. Jakarta.

[5] Qomariyah, Siti. "Vortex pada Bangunan Pengambilan (Intake) Waduk Wonogiri." Media Teknik Sipil 7.2 (2007): 125-130. 